ON THE BACKS OF TORTOISES 


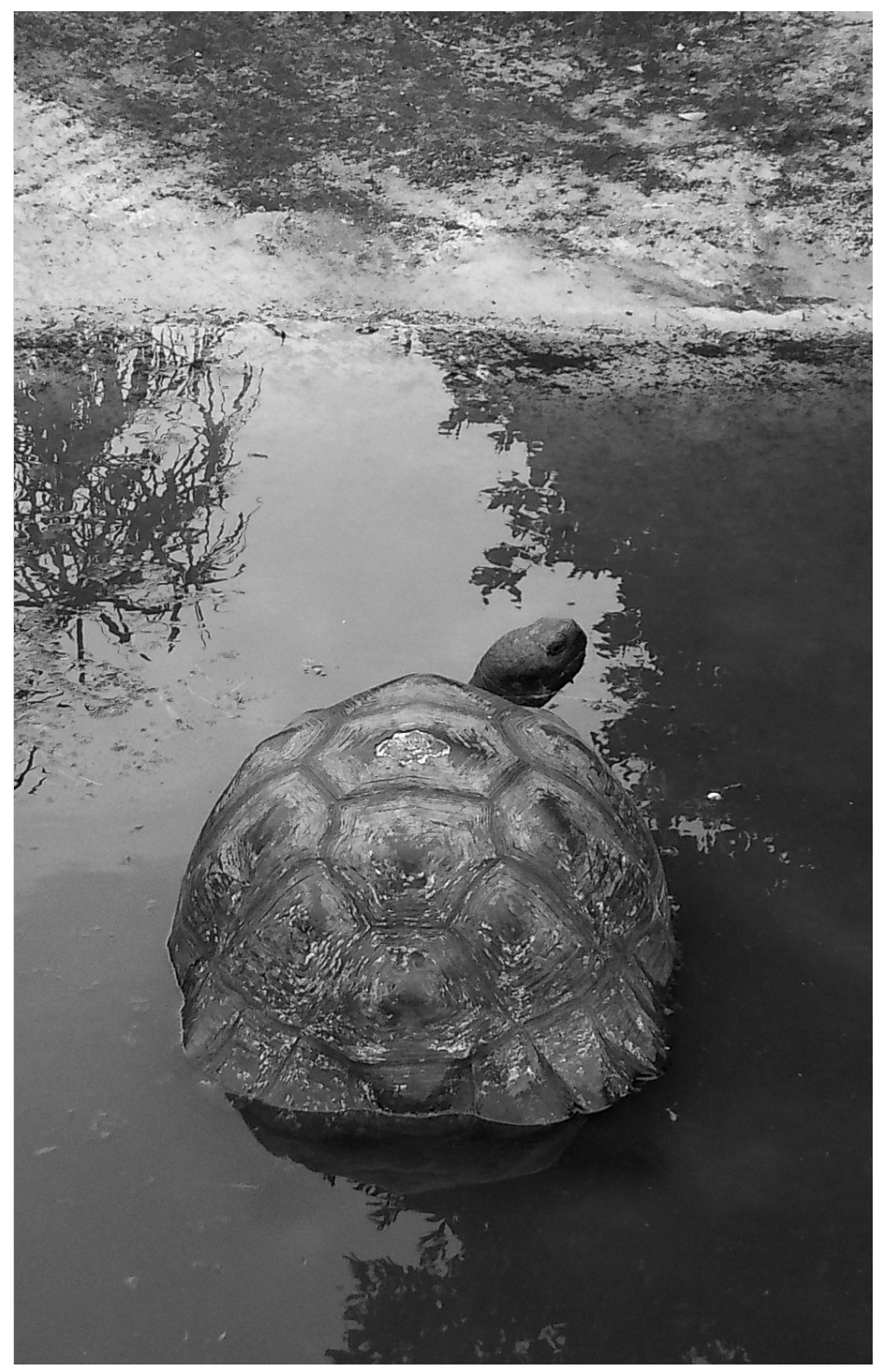




\title{
ON THE BACKS OF TORTOISES
}

\author{
Darwin, the Galápagos, and the \\ Fate of an Evolutionary Eden
}

\author{
ELIZABETH HENNESSY
}

Yale UnIVERsity PRESS NEW HAVEN AND LONDON 
Published with assistance from the Louis Stern Memorial Fund.

Copyright (C) 2019 by Elizabeth Hennessy. All rights reserved.

This book may not be reproduced, in whole or in part, including illustrations, in any form (beyond that copying permitted by Sections I07 and Io8 of the U.S. Copyright Law and except by reviewers for the public press), without written permission from the publishers.

Yale University Press books may be purchased in quantity for educational, business, or promotional use. For information, please e-mail sales.press@yale.edu (U.S. office) or sales@yaleup.co.uk (U.K. office).

Frontispiece: A giant tortoise wades in a pond at Campo

Duro in the highlands of Isabela Island, July 2018.

(Photo by the author)

Set in Scala type by IDS Infotech Ltd., Chandigarh, India. Printed in the United States of America.

Library of Congress Control Number: 201993640I ISBN 978-0-300-23274-5 (hardcover : alk. paper)

A catalogue record for this book is available from the British Library.

This paper meets the requirements of ANSI/NISO Z39.48-I992 (Permanence of Paper).

I0 $9 \begin{array}{lllllllll}9 & 8 & 7 & 6 & 5 & 4 & 3 & 2 & \text { I }\end{array}$ 
for JPH 
This page intentionally left blank 